DOI : https://doi.org/10.31539/jomb.v1i1.599

\title{
ANALISIS CUSTOMER SATISFACTION DAN BRAND TRUST TERHADAP CUSTOMER RETENTION
}

\author{
Gladis Sarah Aurelia ${ }^{1}$, Asep M. Ramdan', Acep Samsudin ${ }^{3}$ \\ Universitas Muhammadiyah Sukabumi ${ }^{1,2,3}$ \\ Email : gladissaraha@yahoo.com ${ }^{1}$
}

\begin{abstract}
ABSTRAK
Tujuan dalam penelitian ini yaitu untuk mengetahui pengaruh customer satisfaction dan brand trust terhadap customer retention. Penggunaan metode dalam penelitian ini adalah menggunakan jenis sampling termasuk kedalam sampel random sampling dan dengan melakukan penyebaran kuesioner sebanyak 101 kepada konsumen. Teknik analisis yang digunakan adalah teknik analisis linear berganda, dan untuk pengujian hipotesis adalah uji statistik secara parsial (uji t) dan uji secara simultan (uji f). Hasil penelitian, uji t menunjukkan bahwa Customer Satisfaction (X1) berpengaruh signifikan terhadap Customer Retention, Brand Trust (X2) berpengaruh signifikan terhadap Customer Retention. Berdasarkan uji $\mathrm{F}$ nilai probabilitas sig $0,000<0,05$ yang berarti bahwa secara bersama-sama Customer Satisfaction (X1) dan Brand Trust (X2) berpengaruh signifikan terhadap Customer Retention (Y). Simpulan, secara simultan, customer satisfaction dan brand trust berpengaruh positif dan signifikan terhadap customer retention pada pengguna shuttle
\end{abstract}

Kata Kunci: Customer Satisfaction, Brand Trust, Customer Retention

\begin{abstract}
The aim this research is to know the influence of customer satisfaction and brand trust toward customer retention. The method of this research is using kind of samples including random samples and questionnaires to 101 consumers. The analytical technique, in here is multiple linear analysis technique, and for the hypotesis testing, we use statistic test partially (testing $t$ ) and simultaneous test (testing f). The reseacrh result for testing $t$ indicates that both customer satisfaction (X1) and brand trust (X2) have significant influence towards customer retention (Y). According to probability value of sig. 0,000 <0,05 means that both satisfaction (X1) and brand trust (X2) have significant influence towards customer retention (Y).
\end{abstract}

Keywords : Customer Satisfaction, Brand Trust, Customer Retention 


\section{PENDAHULUAN}

Topik penelitian mengenai customer retention peneliti mengkaji, selama 20 tahun terakhir. Berdasarkan datanya Chatura Ranaweera \& Jaideep Prabhu (2003), Anders Gustaffsson et al. (2005), Mohamad Dimyati (2015), Fleyti Onecia Kembuan (2015), Eriza Damayanti (2018). Peneliti terdahulu yang mengkaji hubungan Customer Satisfaction dan Brand Trust terhadap Customer Retention. Yang menyatakam dari masing-masing variabel independen memiliki pengaruh terhadap variabel dependen. Di dalam jurnal Chatura Ranaweera (2003), yang berjudul "The influence of satisfaction, trust and switching barriers on customer retention in a continuous purchasing setting”. Menguji hipotesis ini pada data dari survei surat skala besar terhadap pengguna telepon saluran tetap di Inggris, menemukan bahwa kepuasan pelanggan dan kepercayaan pelanggan memiliki pengaruh positif yang kuat pada retensi pelanggan.

Selanjutnya Fleyti Onecia Kembuan (2015) "The Effect Of Price And Brand Trust On Customer Retention At Natasha Skin Care Manado". Tujuan penelitian ini untuk mengetahui pengaruh dari price dan brand trust pada konsumen di Natasha Skin Care Manado. Dengan hasil penelitian menunjukkan bahwa Price dan Bramd Trust (kepercayaan merek) berpengaruh signifikan terhadap Customer Retention (retensi pelanggan).

Persaingan yang ada dalam dunia bisnis mendorong perusahaan untuk menciptakan pemikiran-pemikiran baru mengenai cara mendapatkan pelanggan namun hal yang lebih efektif dilakukan oleh perusahaan adalah dengan mempertahankan pelanggannya. Customer Retention (Retensi pelanggan) merupakan sebuah upaya untuk meningkatkan kinerja sumberdaya perusahaan guna mempertahankan pelanggan. Dengan melakukan beberapa strategi dalam mempertahankan pelanggan, konsumen akan memiliki kesetiaan menggunakan jasa perusahaan tersebut secara terus menerus dalam jangka waktu yang lama. Keuntungannya apabila perusahaan mampu menciptakan customer retention (retensi pelanggan), maka untuk mencapai profitabilitas yang tinggi akan mudah dicapai oleh perusahaan tersebut (Nurfaozi, 2010).

Untuk dapat bertahan dalam ketatnya persaingan dalam dunia bisnis perusahaan harus mampu menciptakan Customer Satisfaction (kepuasan pelanggan), tujuannya agar pelanggan menggunakan produk/jasa suatu perusahaan secara berulang karena kepuasan yang di dapatkan dari perusahaan itu. Dengan menciptakan kepuasan pada 
pelanggan secara tidak langsung akan menambah nilai positif bagi perusahaan, efeknya jika pelanggan sudah merasa puas dengan perusahaan maka kepercayaan pelanggan untuk menggunakan kembali merek tersebut akan meningkat.

Kepercayaan terhadap suatu brand atau merek adalah sikap yang akan muncul dari konsumen sebagai respon positif terhadap suatu merek perusahaan. Kepercayaan dibentuk oleh keyakinan dimana perusahaan memberikan harapan-harapan yang diyakini baik oleh pelanggan. Kepercayaan dianggap sebagai hal yang paling penting guna membangun dan memelihara hubungan dengan konsumen dalam jangka panjang.

Tema yang diusulkan dalam penelitian ini adalah analisis customer satisfaction dan brand trust untuk meningkatkan customer retention pada pengguna shuttle CV. Global Mandiri Wisata Sukabumi. Tujuan penelitian ini untuk mengukur pengaruh customer satisfaction dan brand trust terhadap customer retention pada pengguna shuttle CV. Global Mandiri Wisata Sukabumi.

Dalam penelitian ini peneliti menerapkan metode desktiptif dan asosiatif, dimana metode desktiptif digunakan untuk menjelaskan tentang customer satisfaction, brand trust dan customer retention yang ada pada CV. Global Mandiri Wisata. Sedangkan metode asosiatif digunakan untuk menjelaskan tentang pengaruh customer satisfaction dan brand trust terhadap customer retention yang ada pada CV. Global Mandiri Wisata.

\section{KAJIAN TEORI}

\section{Customer Satisfaction}

Kotler (2018) mendefinisikan Customer Satisfaction (kepuasan pelanggan sebagai) berikut; Kepuasan pelanggan bergantung pada kinerja yang dipersepsikan produk relatif terhadap harapan pembeli. Jika kinerja produk jauh dari harapan, pelanggan tidak merasa puas. Jika kinerja sesuai dengan harapan, pelanggan puas. Jika kinerja melebihi harapan, pelanggan merasa sangat puas atau senang.

Dari definisi tersebut dapat dikatakan apabila kinerja suatu perusahaan jasa tidak sesuai dengan harapan pelanggan dan bila harapan yang ditetapkan terlalu rendah, maka pelanggan tersebut akan merasa tidak puas dan berujung kecewa, jika kinerja sesuai dengan harapan pelanggan akan merasa puas. Menurut Hawkins dan Lonney dikutip dalam Tjiptono (2004) dimensi yang dapat digunakan untuk mengukur kepuasan 
pelanggan antara lain; 1) kesesuaian harapan, 2) minat berkunjung kembali, 3) kesediaan merekomendasikan

\section{Brand Trust}

Brand Trust adalah Harapan yang diberikan kepada pelanggan terhadap suatu merek, dengan harapan perusahaan tersebut dapat memberikan hasil yang positif sesuai yang di harapkan pelanggannya (Damayanti 2018). Menurut Lau dan Lee (Dalam Yulim, 2017) mengukur Dimensi Brand Trust (kepercayaan merek) diukur dari tiga faktor. Hubungan ketiga faktor tersebut dengan kepercayaan merek dapat digambarkan sebagai berikut :

1. Karakteristik Merek (Brand characteristic). Mempunyai peran yang sangat penting dalam menentukan pengambilan keputusan konsumen untuk mempercayai suatu merek. Hal ini disebabkan oleh konsumen melakukan penilaian sebelum membeli. Karakteristik merek yang berkaitan dengan kepercayaan merek meliputi dapat diramalkan, mempunyai reputasi dan kompeten.

2. Karakteristik Perusahaan (Company characteristic), yang ada di balik suatu merek juga dapat mempengaruhi tingkat kepercayaan konsumen terhadap merek tersebut. Pengetahuan konsumen tentang perusahaan yang ada di balik merek suatu produk merupakan dasar awal pemahaman konsumen terhadap merek suatu produk. Karakteristik ini meliputi reputasi suatu perusahaan, motivasi perusahaan yang diinginkan, dan integritas suatu perusahaan.

3. Karakteristik Merek Konsumen (Consumer - brand characteristic). Merupakan dua kelompok yang saling mempengaruhi oleh sebab itu, karakteristik konsumen merek dapat mempengaruhi kepercayaan terhadap merek. Karakteristik ini meliputi kemiripan antara konsep emosional konsumen dengan kepribadian merek, kesukaan terhadap merek, dan pengalaman terhadap merek.

\section{Customer Retention}

Customer Retention merupakan upaya perusahaan dalam memelihara hubungan jangka panjang dengan perusahaan (Buttle, 2007). Customer Retention (Retensi pelanggan) melibatkan mengubah transaksi konsumen individu menjadi hubungan 
pelanggan jangka panjang dengan membuatnya dalam kepentingan terbaik pelanggan untuk tetap bersama perusahaan daripada beralih ke perusahaan lain. (Schiffman, 2015)

Menurut Kotler (dalam Sulistiani et al. 2015) ada tiga dimensi untuk membangun Customer Retention (Retensi Pelanggan) :

1. Financial Benefits (Manfaat Sosial). Retensi pelanggan memberikan keuntungan terhadap perusahaan, hal tersebut karena adanya pembelian yang berulang, serta adanya pembentukan kelompok pelanggan dengan perusahaan dan adanya pemberian penghargaan bagi pelanggan dari perusahaan.

2. Social Benefits (Manfaat Sosial). Membentuk hubungan secara pribadi antara pegawai perusahaan dengan pelanggan dalam menciptakan hubungan jangka panjang dan membangun relasi dengan masing - masing pelanggan secara pribadi.

3. Structural Ties (Ikatan Struktural). Suatu ikatan strutural dimana terbentuk komitmen pada hubungan antara pelanggan dengan perusahaan sehingga tercipta hubungan jangka panjang di antara keduanya.

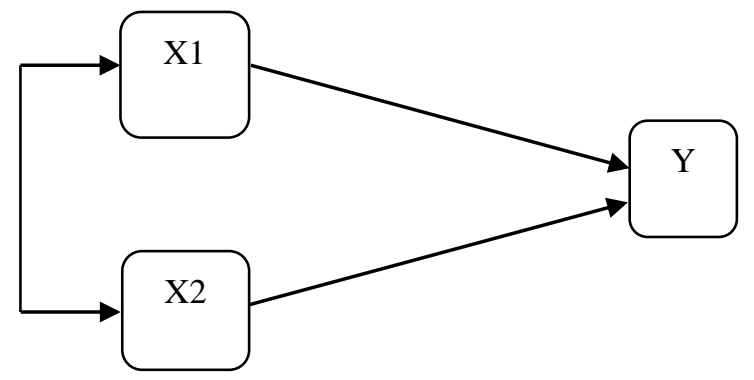

Gambar 1 Paradigma Penelitian

Keterangan :

$\mathrm{X}_{1}=$ Customer Satisfaction

$\mathrm{X}_{2} \quad=$ Brand Trust

$\mathrm{Y} \quad=$ Customer Retention

$\mathcal{E} \quad=$ Faktor lain dalam penelitian ini

\section{METODE PENELITIAN}

Penelitian ini dilaksanakan di CV. Global Mandiri Wisata Kota Sukabumi. Dalam penelitian ini terdapat tiga variabel yang dijadikan kawasan penelitian yaitu 
Customer Satisfaction (Variabel $\mathrm{X}_{1}$ ), Brand Trust (Variabel $\mathrm{X}_{2}$ ) dan juga Customer Retention (Variabel Y). Populasi dalam sampel ini adalah konsumen yang pernah menggunakan jasa CV.Global Mandiri Wisata Kota Sukabumi. Metode yang digunakan adalah menggunakan teknik random sampling dan dengan melakukan penyebaran kuesioner sebanyak 101 kepada responden. Teknik analisis yang digunakan adalah teknik analisis linear berganda, koefisien determinasi dan untuk pengujian hipotesis adalah uji statistik secara parsial (uji t) dan uji secara simultan (uji f).

\section{HASIL PENELITIAN}

Untuk melakukan teknik analisis, peneliti menggunakan bantuan perangkat lunak SPSS 24.

Tabel 1

Koefisien Korelasi antara Customer Satisfaction dan Brand Trust

Terhadap Customer Retention

Model Summary

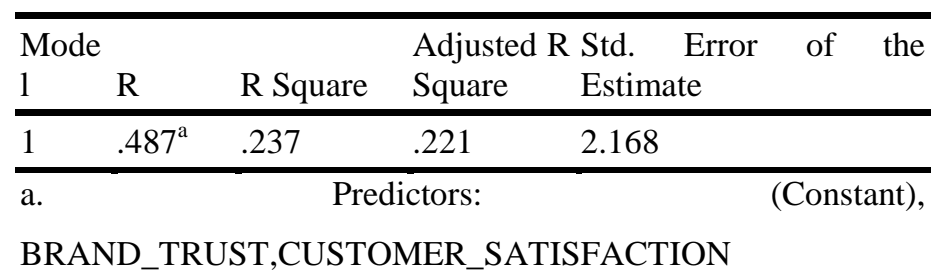

Berdasarkan perhitungan di atas, dapat diketahui bahwa korelasi variabel Customer Satisfaction dan Brand Trust adalah sebesar 0,487 (dlihat nilai R pada tabel di atas).

\section{Koefesien Determinasi}

Penghitungan koefisien determinasi ini dilakukan untuk mengetahui besarnya Customer Satisfaction dan Brand Trust terhadap Customer Retention. Menurut Sugiyono (2014:231) dapat dihitung dengan menggunakan rumus koefisien determinasi sebagai berikut:

$$
\mathrm{Kd}=\mathrm{r}^{2} \times 100 \%
$$


Dimana:

$\mathrm{Kd} \quad=$ Koefisien Determinasi

$\mathrm{r} \quad=$ Koefisien korelasi

Perhitungannya adalah sebagai berikut:

$$
\begin{aligned}
\mathrm{Kd} & =r^{2} \times 100 \% \\
& =(0,487)^{2} \times 100 \% \\
& =0,237 \times 100 \% \\
& =23,7 \%
\end{aligned}
$$

Adapun kriteria untuk koefisien determinasi adalah sebagai berikut, jika "Kd" mendekati 0 , maka pengaruh variabel $\mathrm{X}_{1}$ dan $\mathrm{X}_{2}$ terhadap variabel $\mathrm{Y}$ lemah, jika "Kd" mendekati 1, maka pengaruh variabel $\mathrm{X}_{1}$ dan $\mathrm{X}_{2}$ terhadap variabel $\mathrm{Y}$ kuat. Berdasarkan perhitungan koefisien determinasi yang telah peneliti lakukan, diketahui bahwa nilai Kd $=23,7 \%$ sedangkan sisanya $76,3 \%(100 \%-23,7 \%=76,3 \%)$ dari faktor yang tidak diteliti. Maka dapat disimpulkan bahwa Customer Satisfaction dan Brand Trust terhadap Customer Retention yaitu lemah.

\begin{tabular}{|c|c|c|c|c|c|c|}
\hline \multicolumn{7}{|c|}{ Coefficients $^{\mathrm{a}}$} \\
\hline \multirow[b]{2}{*}{ Model } & & \multicolumn{2}{|c|}{ Unstandardized Coefficients } & \multirow{2}{*}{$\begin{array}{l}\text { Standardized } \\
\text { Coefficients } \\
\text { Beta }\end{array}$} & \multirow[b]{2}{*}{$\mathrm{T}$} & \multirow[b]{2}{*}{ Sig. } \\
\hline & & $\mathrm{B}$ & Std. Error & & & \\
\hline \multirow[t]{3}{*}{1} & (Constant) & 3.044 & 1.134 & & 2.683 & .009 \\
\hline & $\begin{array}{l}\text { CUSTOMER_SATISFAC } \\
\text { TION }\end{array}$ & .244 & .102 & .224 & 2.391 & .019 \\
\hline & BRAND_TRUST & .442 & .115 & .363 & 3.856 & .000 \\
\hline
\end{tabular}

\section{Regresi Linier Berganda}

Tabel 2

Hasil Perhitungan Regresi Linier Berganda

Dari hasil output SPSS 24 di atas, dapat diketahui persamaan regresi ganda yaitu: $a=3,044, b_{1}=0,244, b_{2}=0,442$. Selanjutnya didapat persamaan regresi linier berganda untuk dua predikator (Customer Satisfaction dan Brand Trust) adalah : Y* = $3,044+0,244 X_{1}+0,442 X_{2}$. Berdasarkan persamaan di atas, diketahui terdapat pengaruh 
positif antara Customer Satisfaction (variabel X1) dan Brand Trust (variabel X2) terhadap Customer Retention (variabel Y). Customer retention pada CV. Global Mandiri Wisata akan meningkat, jika Customer Satisfaction (variabel X1) dan Brand Trust (variabel X2) ditingkatkan. Adapun koefisien regresi untuk customer satisfaction sebesar 0,244 lebih kecil dari pada koefisien regresi untuk brand trust sebesar 0,442

\section{Uji Secara Parsial T}

Untuk mengetahui hasil pengujian masing-masing variabel independen terhadap variabel dependen. Yang dimana terdiri variabel dependen terdiri dari customer satisfaction dan brand trust, sedangkan variabel dependennya adalah customer retention. Data yang digunakan untuk perhitungan uji t selanjutnya, dimasukan dan dihitung melalui perangkat lunak SPSS 24. Adapun hasil perhitungan tersebut adalah sebagai berikut.

Tabel 3

Hasil Pengujian Hipotesis (Uji T)

Coefficients $^{\mathrm{a}}$

\begin{tabular}{|c|c|c|c|c|c|c|}
\hline \multirow[b]{2}{*}{ Model } & & \multicolumn{2}{|c|}{ Unstandardized Coefficients } & \multirow{2}{*}{$\begin{array}{c}\begin{array}{c}\text { Standardized } \\
\text { Coefficients }\end{array} \\
\text { Beta }\end{array}$} & \multirow[b]{2}{*}{$\mathrm{T}$} & \multirow[b]{2}{*}{ Sig. } \\
\hline & & B & Std. Error & & & \\
\hline \multirow[t]{3}{*}{1} & (Constant) & 3.044 & 1.132 & & 2.683 & .009 \\
\hline & $\begin{array}{l}\text { CUSTOMER_SATIS } \\
\text { FACTION }\end{array}$ & .244 & .102 & .224 & 2.391 & .019 \\
\hline & BRAND_TRUST & .442 & .115 & .362 & 3.85 & .000 \\
\hline
\end{tabular}

a. Dependent Variable: CUSTOMER_RETENTION

Dapat ditarik kesimpulan bahwa variabel customer satisfaction dengan nilai sig. $0,19<0,05 \mathrm{t}_{\text {hitung }} 2,391>1.98422 \mathrm{t}_{\text {tabel }}$, artinya customer satisfaction berpengaruh positif dan signifikan secara parsial terhadap customer retention. Maka $\mathrm{H}_{1}$ : Customer Satisfaction berpengaruh terhadap Customer Retention Pada Pengguna Shuttle CV. Global Mandiri Wisata Kota Sukabumi, diterima .

Selanjutnya untuk variabel brand trust nilai nilai sig. $0,000<0,05$, nilai $\mathrm{t}_{\text {hitung }}$ $3,85>1.98422 \mathrm{t}$ tabel, artinya brand trust berpengaruh positif dan signifikan secara parsial terhadap customer retention. Maka $\mathrm{H}_{2}$ : Brand Trust berpengaruh terhadap 
Customer Retention Pada Pengguna Shuttle CV. Global Mandiri Wisata Kota Sukabumi, diterima .

\section{Uji Secara Simultan (Uji F)}

Tabel 4

Hasil Pengujian Hipotesis (Uji T)

\begin{tabular}{|c|c|c|c|c|c|c|}
\hline \multicolumn{7}{|c|}{ ANOVA } \\
\hline Model & & Sum of Squares & Df & Mean Square & $\mathrm{F}$ & Sig. \\
\hline \multirow{3}{*}{1} & Regression & 143.022 & 2 & 71.511 & 15.220 & $.000^{\mathrm{b}}$ \\
\hline & Residual & 460.444 & 98 & 4.698 & & \\
\hline & Total & 603.465 & 100 & & & \\
\hline \multicolumn{7}{|c|}{ a. Dependent Variable: CUSTOMER_RETENTION } \\
\hline \multicolumn{7}{|c|}{ b. Predictors: (Constant), BRAND_TRUST, CUSTOMER_SATISFACTION } \\
\hline
\end{tabular}

Berdasarkan perhitungan diatas, didapatkan hasil $\mathrm{F}$ hitung variabel $X 1$ (Customer Satisfaction), X2 (Brand Trust), dan Y (Customer Retention) adalah sebesar 15.220 Selanjutnya nilai $\mathrm{F}$ hitung tersebut dibandingkan dengan nilai $\mathrm{F}$ tabel. $\mathrm{F}$ tabel dicari pada tabel yang tertera pada lampiran dengan berdasarkan pada $\mathrm{dk}$ pembilang $=\mathrm{k}$ dan $\mathrm{dk}$ penyebut $=(\mathrm{n}-\mathrm{k}-1)$ dan taraf kesalahan yang ditetapkan. Adapun taraf kesalahan yang ditetapkan adalah sebesar $5 \%$, jadi dk pembilang 2 , dan $\mathrm{dk}$ penyebut $=98$, sehingga diperoleh nilai $\mathrm{F}$ tabel $=3,09$.

Hal tersebut dapat disimpulkan bahwa terdapat pengaruh yang signifikan antara variabel X1, X2 dan Y. Adapun hasil pengujian hipotesisnya adalah sebagai berikut : F hitung $\geq F$ table 15,220 > 3,09. Dari hasil uji f yang dilakukan, diperoleh nilai sig. 0,000 $<0,05$, nilai $15,220 \mathrm{~F}_{\text {hitung }}>\mathrm{F}_{\text {tabel }}$ 3,09. Artinya bahwa customer satisfaction dan brand trust secara bersama-sama (simultan) berpengaruh terhadap customer retention. Maka $\mathrm{H}_{3}$ : Customer Retention dan Brand Trust Berpengaruh terhadap Customer Retention, diterima.

\section{PEMBAHASAN}

\section{Customer Satisfaction berpengaruh terhadap Customer Retention}

Hasil penelitian ini sama dengan penelitian (Dewi dan Nanang, 2013), dimana Customer Satisfaction berpengaruh positif dan signifikan terhadap Customer Retention (Y) secara parsial hal ini dapat dibuktikan dari hasil pengujian uji t menunjukkan nilai sig. $0,000<0,05$, nilai $\mathrm{t}_{\text {hitung }} 2,391>1.98422 \mathrm{t}$ tabel, maka dapat disimpulkan bahwa Ho 
ditolak dan Ha diterima. Maka menunjukkan bahwa Customer satisfaction memberikan nilai positif dalam mempengaruhi customer retention pada perusahaan.

Menurut ClientHeartBeat (dalam Qonitat et al 2018) kepuasan menunjukan bahwa diperkirakan tidak lebih dari $30 \%$ pelanggan yang tetap menggunakan produk/jasa yang sama saat ia mengalami ketidakpuasan ataupun saat keluhannya tidak direspon oleh pemegang merek. Penelitian ini sesuai dengan teori (Dewi dan Nanang, 2013), dengan adanya kepuasan pelanggan yang tinggi maka pelanggan enggan untuk berpindah ke produk lain dan melakukan pembelian dalam frekuensi yang terus menerus dalam jangka waktu yang panjang (customer retention). Yang artinya hasil dari penelitian ini bahwa Customer satisfaction memberikan nilai positif dalam mempengaruhi customer retention, karna manfaat yang dirasakan pelanggan menimbulkan kepuasan pelanggan yang tinggi dan menciptakan customer retention dimana pelanggan melakukan pembelian ulang produk/jasa dalam jangka waktu yang panjang.

\section{Brand trust Berpengaruh Terhadap Customer Retention}

Hasil penelitian ini sama dengan penelitian Kembuan (2015), dimana Brand trust berpengaruh positif dan signifikan terhadap (Y) secara parsial. Hal ini dapat dibuktikan dari hasil pengujian uji t menunjukkan nilai sig. $0,000<0,05$, nilai $\mathrm{t}_{\text {hitung }}$ $1,495>1.98422 \mathrm{t}$ tabel, artinya brand trust berpengaruh positif dan signifikan secara parsial terhadap customer retention pada perusahaan.

Menjaga kepercayaan pelanggan terhadap merek perusahaan adalah yang penting dilakukan. Kepercayaan merupakan salah satu alasan pelanggan mau membeli atau menggunakan suatu produk/jasa yang ada di dalam perusahaan. Pelanggan yang percaya bahwa suatu merek perusahaan dapat memberikan kinerja yang baik serta memenuhi harapannya, maka pelanggan tersebut akan memiliki kecenderungan untuk lebih sering memakai suatu merek tersebut dibanding merek yang lain.

\section{Customer Retention dan Brand Trust Berpengaruh terhadap Customer Retention}

Hasil penelitian ini sama dengan penelitian Nurfaozi (2010), dengan hasil penelitian Customer satisfaction dan brand trust berpengaruh positif dan signifikan terhadap customer retention secara simultan. Hal ini dapat dibuktikan Dari hasil uji $\mathrm{f}$ 
yang dilakukan, diperoleh nilai sig. 0,000 $<0,05$, nilai $15.220 \mathrm{~F}_{\text {hitung }}>\mathrm{F}_{\text {tabel }} 3,09$. Artinya bahwa customer satisfaction dan brand trust secara bersama-sama (simultan) berpengaruh terhadap customer retention pada perusahaan.

Kepuasan pelanggan itu berkaitan dengan harapan pelanggan yang dapat di penuhi oleh perusahaan. Namun untuk mencapai tujuan perusahaan dalam menciptakan customer retention agar pelanggan menggunakan produk/jasa perusahaan dalam jangka waktu yang panjang, tidak hanya dapat mengandalkan kepuasan pelanggan saja. Salah satunya adalah dengan kercayaan pelanggan terhadap merek, dapat menjadi salah satu faktor perusahaan dalam menciptakan customer retention (Fadillah 2015). Hasil penenelitian ini sesuai dengan teori menurut Fadillah (2015) dimana customer satisfaction dan brand trust berpengaruh secara postif dan signifikan secara bersamasama terhadap customer retention.

\section{SIMPULAN}

1. Secara parsial, customer satisfaction berpengaruh dan signifikan terhadap customer retention pada pengguna shuttle CV. Global Mandiri Wisata Kota Sukabumi.

2. Secara parsial, brand trust berpengaruh dan signifikan terhadap customer retention pada pengguna shuttle CV. Global Mandiri Wisata Kota Sukabumi.

3. Secara simultan, Customer satisfaction dan brand trust berpengaruh positif dan signifikan terhadap customer retention pada pengguna shuttle CV. Global Mandiri Wisata Kota Sukabumi.

\section{DAFTAR PUSTAKA}

Buttle, F. (2007). Customer Relationship Management. Malang: Bayumedia.

Damayati, E. (2018). Studi Tentang Customer Retention Sriwijaya Air pada Penumpang di Bandara Adi Soemarno Solo. Intitut Agama Islam Negeri Surakarta: Tidak Diterbitkan.

Dimyati, M. (2015). Customer Satisfaction and Switching Cost Toward Trust In The Brand And Customer Retention. International Refeered Research Journal, 6 (2)

Fadillah, A. (2015). Pengaruh Customer Satisfaction dan Trust in a Brand terhadap Customer Retenntion. STIE Kesatuan

Gustaffson, A. (2005). The Effect of Customer Satisfaction, Relationship Commitment Dimensions, and Triggers on Customer Retention. Journals Of Marketing , 69 (1), 210-218.

Kembuan, F. O. (2015). The Effect Of Price and Brand Trust On Customer Retention At Natasha Skin Care Manado. Jurnal Berkala Ilmiah Efisiensi, 15 (5) 
Kotler, P. (2018). Principles Of Marketing . United Kingdom: Pearson Education United.

Nanang dan Dewi. (2013). Pengaruh Kepuasan Pelanggan dan Switching Barrier Terhadap Customer Retention. Universitas Brawijaya.

Nurfaozi, A. (2010). Analisis Pengaruh Customer Satisfaction, Brand Trust dan Switching Barrier Terhadap Customer Retention Dalam Pembelian Berkelanjutan. Universitas Sebelas Maret Surakarta: Tidak Diterbitkan.

Qonitat. (2018). Analisis Pengaruh Customer Satisfactio dan Switching Barrier Terhadap Customer Retention Kartu GSM. Jurnal Administrasi Bisnis, 55 (2)

Ranaweera, C. (2003). The Influence of Satisfaction, Trust and Switching Barriers on Customer Retention in a continuous purchasing setting. International Journal of Service Industry Management, 14 (4)

Schiffman, L. G. (2015). United States of America: Courier Kendallville.

Sulistiani, F. (2015). Pengaruh Kepercayaan, Komitmen dan Komunikasi Terhadap Retensi Pelanggan Dengan Kepuasan Pelanggan Sebagai Variabel Intervening (. Diponegoro Journal of Social and Political of Science .

Tjiptono, F. (2004). Manajemen Pemasaran, Edisi Kedua. Yogyakarta: Andi Offset.

Yulim, R. (2017). Pengaruh Dimensi Kepercayaan Merek Terhadap Loyalitas Merek Konsumen Shampoo Clear. Universitas Lampung: Tidak Diterbitkan. 